\title{
PERANCANGAN SISTEM INFORMASI PELAYANAN JASA LAUNDRY PADA MAMAH LAUNDRY AND CLEANERS SERANG
}

\author{
Hesti Rian', \\ Manajemen Informatika \\ Politeknik LP3I Jakarta \\ hestiriangustiawan@gmail.com
}

\author{
Anwar Fuadytama ${ }^{2}$ \\ Manajemen Informatika \\ Politeknik LP3I Jakarta \\ bhetagodeg@gmail.com
}

\begin{abstract}
Abstrak - Sistem informasi sangat dibutuhkan dalam proses pendataan dalam sebuah kegiatan di sebuah organisasi atau bidang usaha. Seperti kegiatan pelayanan jasa laundry pada Mamah Laundry and Cleaners yang memerlukan data yang tepat sehubungan dengan data laundry yang akan dikerjakan dan diterima dari pelanggan. Penelitian ini dilakukan untuk membuat perancangan sistem informasi pelayanan jasa laundry yang diharapkan dapat membantu dan mempermudah dalam memberikan pelayanan dalam kegiatan laundry yang dilakukan pada Mamah Laundry and Cleaners dengan perancangan sistem menggunakan Unified Modeling Language(UML) dan bahasa pemrograman PHP.
\end{abstract}

\section{Keywords : sistem informasi, perancangan, pelayanan jasa laundry}

\section{PENDAHULUAN}

Teknologi saat ini bisa dikatakan sebagai kebutuhan pokok. Pasalnya seluruh kegiatan manusia tidak terlepas dari teknologi. Tidak pandang bulu, berbagai usia dari muda sampai yang tua menikmati teknologi pada setiap kegiatan mereka. Teknologi berkembang sangat cepat terutama mengenai komputerisasi. Perkembangan teknologi menuntut penggunanya agar mengikuti perkembangannya.

Dampak perkembangan teknologi adalah memanjakan perusahaan jasa pelayanan. Dengan menerapkan teknologi pada sistem perusahaan jasa pelayanan maka karyawannya akan terbantu dalam pekerjaannya, sehingga pekerjaanya akan lebih efisien juga meminimalisir tingkat kesalahan yang disebabkan oleh human error.

Pada zaman ini, teknologi yang digunakan di banyak perusahaan jasa pelayanan yaitu sistem komputerisasi. Sistem tersebut dinilai lebih menjanjikan daripada sistem manual yang dahulu mereka gunakan. Tidak semua pekerjaan mereka aplikasikan dengan sistem komputerisasi, sehingga lebih memilih sistem manualnya. Seperti sistem pelayanan jasa laundry. Dengan sistem yang masih manual dalam pendataan pakaian masuk dan pakaian keluar, kemungkinan terjadinya kesalahan terbilang besar. Oleh karena itu, penulis tertarik untuk mengambil judul Perancangan Sistem Informasi
Pelayanan Jasa Laundry pada Mamah Laundry And Cleaners.

Rumusan masalah dalam penelitian ini adalah bagaimana proses pelayanan jasa pada Mamah Laundry And Cleaners, adakah kendala pada proses pelayanan jasa dan bagaimana solusi pemecahan masalah terhadap kendala tersebut.

Berdasarkan rumusan masalah di atas, maka tujuan penelitian ini adalah untuk mengetahui proses dan kendala pelayanan jasa pada Mamah Laundry And Cleaners serta menemukan solusi pemecahan masalah terhadap kendala tersebut.

\section{TINJAUAN PUSTAKA}

\section{A. Perancangan}

Menurut Rusdi Nur dan Muhammad Arsyad Suyuti dalam buku yang berjudul "Perancangan Mesin - Mesin Industri" (2018:5) menyebutkan bahwa "Suatu proses yang bertujuan untuk menganalisis, Menilai memperbaiki dan menyusun suatu sistem, baik fisik maupun non fisik yang optimum untuk waktu yang akan datang dengan memanfaatkan informasi yang ada".

\section{B. Sistem Informasi}

Sri Mulyani (2016) dalam buku yang berjudul "Metode Analisa dan Perancangan Sistem" (2016:2) menyebutkan bahwa : "Sistem adalah kumpulan dari dua atau lebih kompunen yang saling bekerja dan berhubungan untuk mencapai tujuan tertentu”.

Menurut Kusrini (Universitas Amikom) dalam buku "Tuntunan Praktis Memnagnun Sistem Informasi Akutansi dengan Visual Basic dan Microsoft SQL Server + CD. Penerbit Andi" menyebutkan bahwa "Informasi adalah data yang sudah diolah menjadi sebuah bentuk yang berarti bagi pengguna, yang bermanfaat dalam pengambilan keputusan saat ini atau mendukung sumber informasi.".

\section{Pelayanan}

"Pelayanan adalah setiap kegiatan yang menguntungkan dalam suatu kumpulan atau kesatuan, dan menawarkan kepuasan meskipun hasiilnya tidak terikat pada suatu produk secara fisik" (Kotler dalam Lukman) dalam buku Daryanto (2014:135). 


\section{Jasa}

Menurut Lopiyoadi (2014:7) dalam bukunya "Manajemen Pemasaran Jasa": "Jasa adalah setiap tindakan atau kegiatan yang dapat ditawarkan oleh suatu pihak kepada pihak lain, pada dasarnya tidak berwujud dan tidak mengakibatkan perpindahan kepemilikan apapun. Produk jasa mungkin berkaitan dengan produk fisik atau tidak.”

\section{E. Laundry}

Agustinus Darsono (2016:94) dalam bukunya "Housekeeping Hotel" menyebutkan bahwa: "Laundry adalah bagian hotel yang bertanggung jawab terhadap pencucian, baik itu pencucian pakaian tamu, seragam karyawan maupun linen-linen hotel."

\section{F. Flowchart}

Indrajani (2015:36) dalam bukunya yang berjudul "Database Design (Case Study All in One)" menyebutkan bahwa "Flowchart adalah penggambaran secara grafik dari langkah-langkah dan urutan prosedur suatu program.”

\section{G. Use Case}

Menurut Rosa A. S dan M Shalahuddin (2015:155) dalam bukunya yang berjudul "Rekayasa Perangkat Lunak Terstruktur dan Berorientasi Objek" Use Case adalah: "Pemodelan untuk kelakuan (behavior) system informasi yang akan dibuat, use case mendeskripsikan sebuah interaksi antara satu atau lebih actor dengan sistem informasi yang akan dibuat”.

\section{H. Activity Diagram}

Menurut Rosa A. S dan M Shalahuddin (2015:161) dalam bukunya yang berjudul "Rekayasa Perangkat Lunak Terstruktur dan Berorientasi Objek" Activity Diagram adalah: "Menggambarkan aliran kerja (workflow) atau aktivitas dari sebuah system atau proses bisnis atau menu yang ada pada perankat lunak".

\section{Class Diagram}

Definisi Class Diagram menurut Rosa A.S dan M. Shalahuddin (2015:141) dalam bukunya "Rekayasa Perangkat Lunak Terstruktur dan Berorientasi Objek" menyebutkan bahwa "Class Diagram mengambarkan struktur sistem dari segi pendefinisian kelas-kelas yang akan dibuat untuk membangun sistem ".

\section{J. Sequence Diagram}

Definisi Sequence Diagram menurut Rosa A.S dan M. Shalahuddin (2015:161) dalam bukunya "Rekayasa Perangkat Lunak Terstruktur dan Berorientasi Objek" menyebutkan bahwa "Sequence Diagram mengambarkan kelakuan objek pada use case dengan mendeskripsikan waktu hidup objek dan message yang dikirimkan dan diterima antar objek".

\section{K. Database}

Yudi Priyadi (2014:2) dalam bukunya "Kolaborasi SQL dan ERD Dalam Implementasi Database": "Secara umum, pengertian basis data adalah sekumpulan fakta berupa represantasi tabel yang saling berhubungan dan disimpan dalam media penyimpanan secara digital. Dalam suatu basis data terdiri dari sekumpulan tabel yang saling berelasi ataupun tidak berelasi. Semua tabel tersebut Asosiasi Berarah / Directed Association Relasi antarkelas dengan makna kelas yang satu digunakan oleh kelas yang lain, asosiasi biasanya juga disertai dengan multiplicity. Generalisasi Relasi antarkelas dengan makna generalisasi spesialisasi (umumkhusus). Ketergantungan Relasi antarkelas dengan makna ketergantungan antarkelas. Agregasi / Aggregation Relasi antarkelas dengan makna semua-bagian (whole-part). merupakan representasi tempat untuk penyimpanan data, yang mendukung fungsi dari basis data tersebut untuk suatu system”. 
HASIL DAN PEMBAHASAN

Flowchart Alir Dokumen

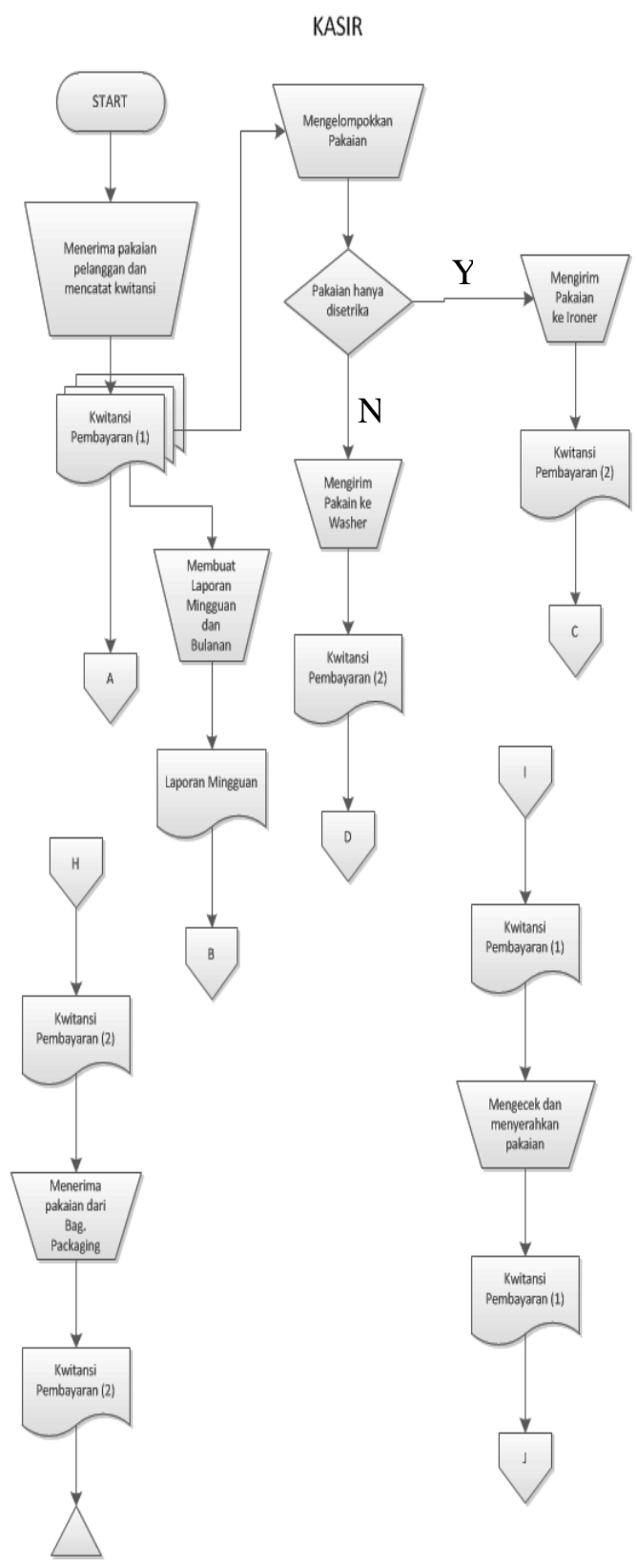

PELANGGAN

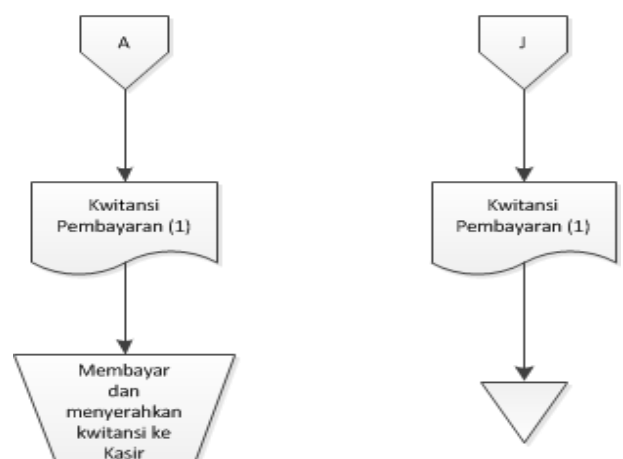




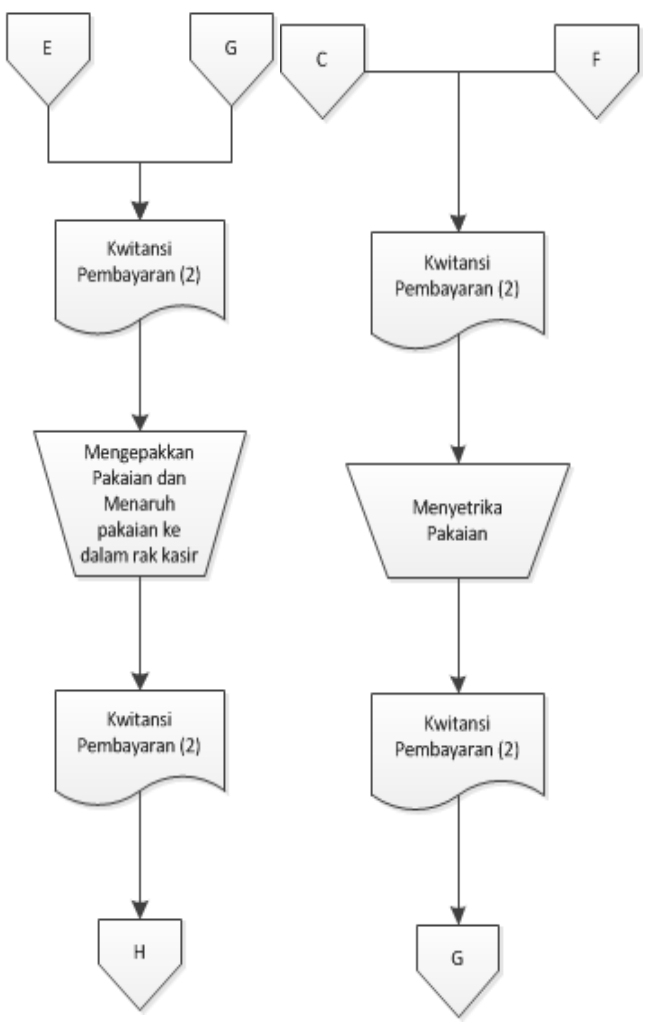

MANAJER LAUNDRY

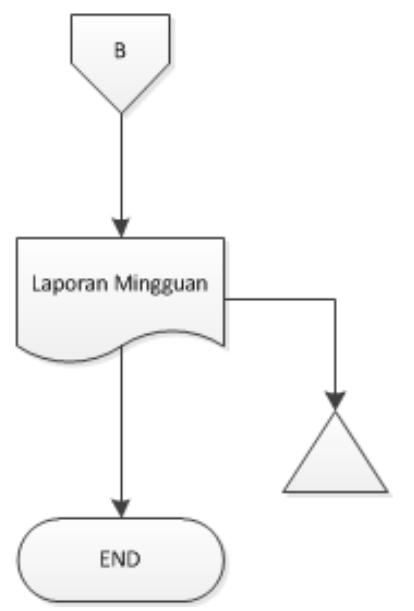

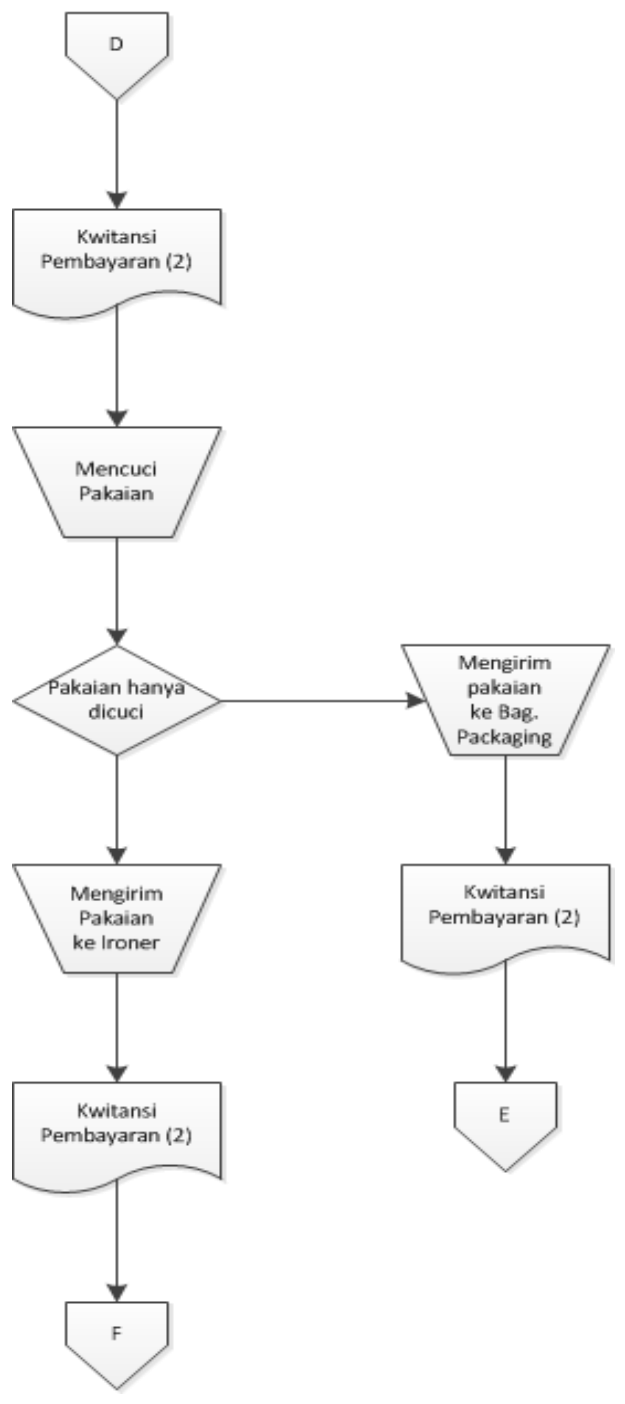




\section{Use Case Diagram}

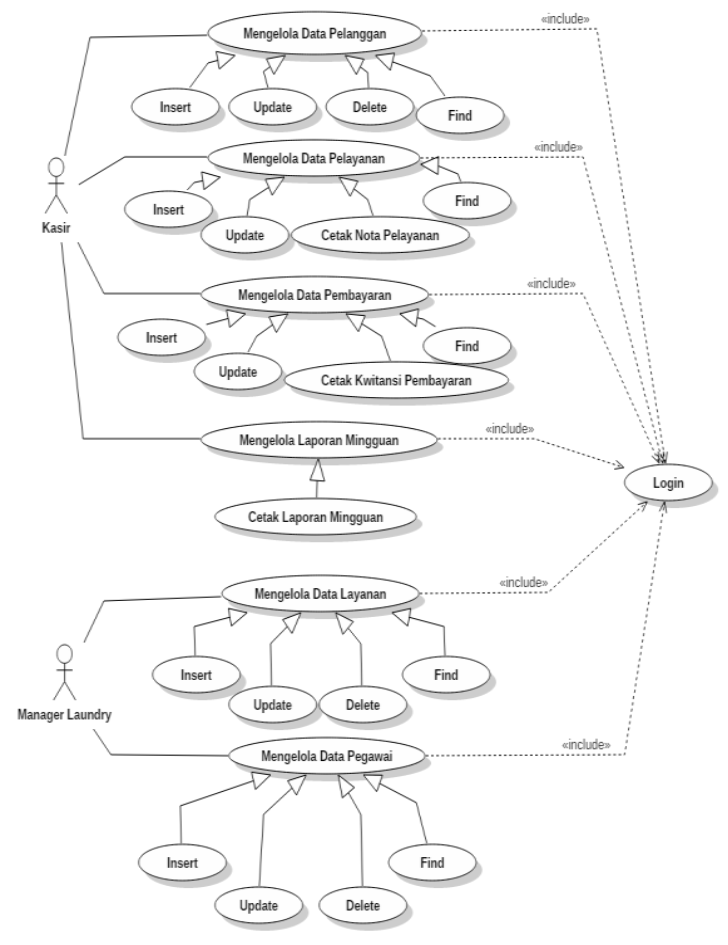

\section{Class Diagram}

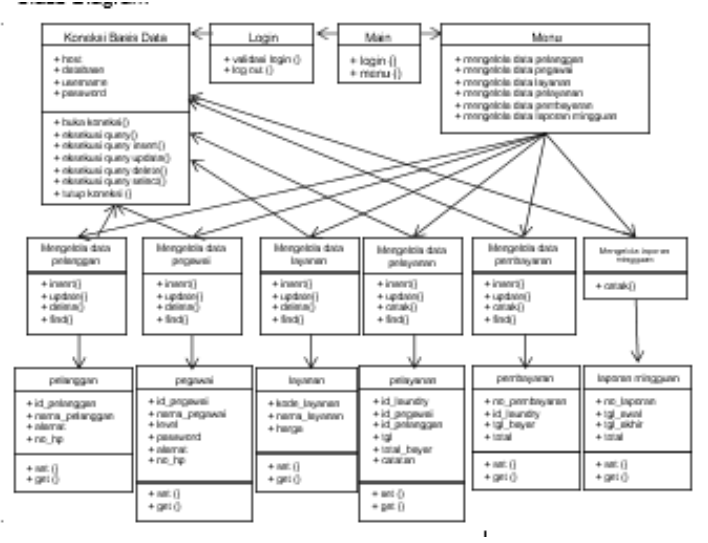

\section{Relasi Antar Tabel}

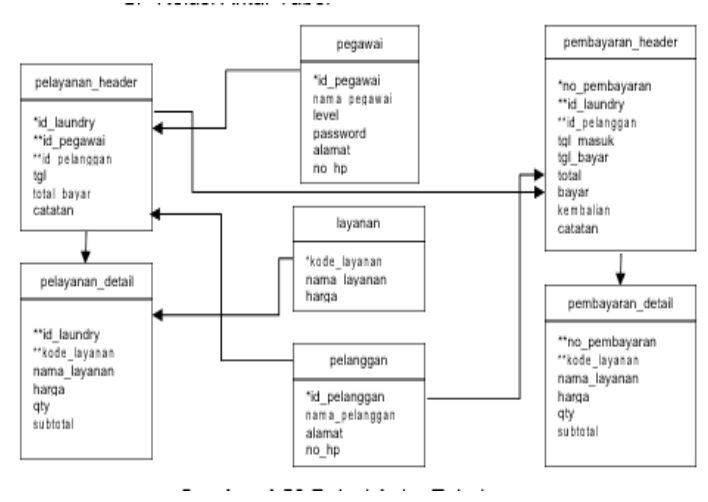

\section{Kebutuhan Infrastruktur}

Adapun perangkat yang dibutuhkan adalah :

1. Sistem Operasi
a. Windows 7 Ultimate

2. Kebutuhan Hardware
a. Processor Intel Pentium CPU B980 $2.40 \mathrm{GHz}$
b. RAM DDR3 PC $54002 \mathrm{~GB}$
c. Harddisk Toshiba 500GB (5400rpm)
d. LG 19"' Type Flatron W1953SE

3. Kebutuhan Device
a. Printer HP Diskjet Ink Advantage 2545

\section{KESIMPULAN}

Adanya penumpukan dokumen yang tidak rapih sehingga apabila dokumen dibutuhkan sulit dicari maka untuk mengatasi masalah yang terkait dengan pembuatan laporan perlu menggunakan sistem komputerisasi yang terintegrasi dengan database sehingga memudahkan pembuatan laporan dan mengefisiensikan kinerja bagian kasir melakukan kegiatan pelayanan.

\section{DAFTAR PUSTAKA}

Darsono, Agustinus. Housekeeping Hotel. Jakarta: Gramedia Widiasarana Indonesia, 2016.

Effendy, Muhadjir. Kamus Besar Bahasa Indonesia Edisi Kelima. Jakarta: Menteri Pendidikan dan Kebudayaan, 2016.

Hidayatullah, Priyanto. Visual Basic .NET. Edisi Revisi. Bandung: Informatika, 2014.

Hutahaean, Jeperson. Konsep Sistem Informasi. Yogyakarta: Deepublish, 2015.

Idrajani. Database Design (Case Study All in One). Jakarta: PT Elex Media Komputindo, 2015

Lopiyoadi. Manajemen Pemasaran Jasa. Jakarta: Salemba Empat, 2014. 
Prahasta, Eddy. Sistem Informasi Geografis

Konsep-Konsep Dasar

Bandung: Informatika Bandung, 2014.

Priyadi, Yudi. Kolaborasi SQL \& ERD

Dalam Implementasi Database.

Yogyakarta: Penerbit Andi, 2014.

Rosa, A,S, Shalahuddin, M. Rekayasa

Perangkat Lunak. Bandung:

Informatika Bandung, 2014.

Tohari, Hamim. Analisis Serta

Perancangan Sistem Informasi

Melalui Pendekatan UML.

Yogyakarta: Penerbit Andi, 2014. 